\title{
Two new cis-Andean species of the South American catfish genus Megalonema allied to trans-Andean Megalonema xanthum, with description of a new subgenus (Siluriformes: Pimelodidae)
}

\author{
John G. Lundberg and Wasila M. Dahdul
}

A revised diagnosis of the pimelodid catfish genus Megalonema is given based on synapomorphic features of the Weberian complex and gas bladder. Megalonema xanthum from the Magdalena River is redescribed. Two new cis-Andean species of Megalonema are described, M. amaxanthum n. sp. from the Amazon River basin, and M. orixanthum n. sp. from the Orinoco River basin. These three species are differentially diagnosed by shape and size of the supraoccipital posterior process, adipose-fin shape, vertebral counts, eye size, premaxillary bone shape and dentition, length of the anal-fin base, width between the posterior nostrils and presence/absence of dentations on the pectoral spine. Eretmomegalonema new subgenus is established for M. xanthum, M. amaxanthum and M. orixanthum and supported by the uniquely synapomorphic paddle-like structure of its pelvic fin and hypertrophied basipterygium. Unambiguous synapomorphies indicate a sister-group relationship between $M$. amaxanthum and $M$. orixanthum, with $M$. xanthum basal to this pair. This topology is congruent with the Neogene origins of separate Magdalena, Amazon and Orinoco basins suggesting vicariant control of diversification of Eretmomegalonema.

Uma diagnose do gênero Megalonema é fornecida baseada em caracteres sinapomórficos do aparelho de Weber e da bexiga natatória. Megalonema xanthum do rio Magdalena, é redescrita. Duas novas espécies cis-Andinas de Megalonema são descritas: M. amaxanthum sp. n. da bacia Amazônica, e M. orixanthum da bacia do rio Orinoco. Estas três espécies são diagnosticadas pela forma e tamanho do processo supraoccipital posterior, forma da nadadeira adiposa, contagem do número de vértebras, tamanho do olho, forma do premaxilar e dentição, comprimento da base da nadadeira anal, distância entre as narinas posteriores, e presença/ausência de dentições no espinho da nadadeira peitoral. Eretmomegalonema, novo subgênero, é estabelecido para M. xanthum, M. amaxanthum e M. orixanthum e suportado pelas únicas estruturas sinapomórficas da nadadeira pélvica em forma de remo, e do basipterígio hipertrofiado. Claras sinapomorfias indicam uma relação de grupo irmão entre $M$. amaxanthum e $M$. orixanthum, com $M$. xanthum basal a esse grupo. Esta topologia é congruente com a origem Neogênica das distintas bacias do Magdalena, Amazonas e Orinoco, sugerindo um evento vicariante de diversificação de Eretmomegalonema.

Key words: Eretmomegalonema, Megalonema amaxanthum, Megalonema orixanthum.

\section{Introduction}

The pimelodid catfish genus Megalonema has an ample distribution in South America throughout the Paraná, Amazon, Essequibo, Orinoco, Maracaibo and Magdalena basins. The species of Megalonema inhabit medium to large rivers mostly in flowing marginal reaches and over fine substrates of mud or sand. These are streamlined catfishes of modest size with adult lengths ranging among species from ca. 10-30 cm SL. Their clear to hyaline fins are gracefully shaped and often filamentous, with flexible fin spines in the dorsal and pectoral fins, and an expansive adipose fin. In color Megalonema are mostly plain yellowish to tan and generally without prominent marks except for the common presence of an embedded dark spot in the base of the upper caudal-fin lobe, and sometimes also the lower lobe.

Department of Ichthyology, The Academy of Natural Sciences, 1900 Benjamin Franklin Parkway, Philadelphia, PA 19103-1195, USA. lundberg@ansp.org(JGL), dahdul@ansp.org (WMD) 
Carl Eigenmann (1912a) established the genus Megalonema for his newly described species $M$. platycephalum from the Essequibo River, Guyana. Later in the same year he described a second species, M. xanthum, from the río Magdalena, Colombia (Eigenmann, 1912b). Subsequent species descriptions and taxonomic transfers have raised the number of presumed valid species in Megalonema to six (Lundberg \& Littmann, 2003). The existence, however, of at least one undescribed cis-Andean species has been known for over 25 years and our recent study of Amazon and Orinoco populations indicates additional undescribed species. The purpose of this paper is to describe two new species that are related to $M$. xanthum, and to recognize these three as a monophyletic subgroup of Megalonema characterized by oddly hypertrophied pelvic fins. In a subsequent paper we are revising the remaining species of the genus.

\section{Material and Methods}

Measurements and counts follow Lundberg et al. (1991), Lundberg \& Parisi (2002) and Lundberg \& Akama (2005) with the addition of the distance from snout tip to insertion of outer pelvic-fin ray, and least distance from orbital margin to posterior nostril. Measurements are straight-line distances taken with a digital caliper to the nearest $0.1 \mathrm{~mm}$ from a sample of 136 specimens ranging in standard length (SL) from 38.2 to $120.0 \mathrm{~mm}$. Measurement ratios are expressed in thousandths (mils) in text and Table. We used least squares regression to analyze variation in $\log 10$ transformed variables, and t-tests of the residuals from regression lines to assess taxonomic differences in proportional measurements. Vertebral counts include the five elements united in the Weberian complex; the first caudal vertebra is that immediately posterior of the visceral cavity and recognized by its fully developed hemal spine; the compound centrum of the caudal skeleton is counted as one. Radiographed (R), cleared and stained (C\&S), and articulated dry skeletal (Sk) specimens were used for counts of vertebrae and median-fin rays. Institutional acronyms are as listed on the Catalog of Fishes website at http:// www.calacademy.org/research/ichthyology/catalog/ abtabr.html.

\section{Results}

The genus Megalonema possesses nearly all of the diagnostic synapomorphies for the following nested groups (Lundberg et al., 1991: 842, fig. 1; see also Hardman \& Lundberg, 2006): Pimelodidae sensu Lundberg \& Littmann (2003), non-phractocephaline pimelodids (i.e., all Pimelodidae except Steindachneridion, Phractocephalus, Leiarius, Perrunichthys), and the Calophysus-Pimelodus clade. Megalonema is exceptional among Pimelodidae in lacking a deep sutural joint between the fifth and sixth centra. In the framework of its inferred phylogenetic position in Pimelodidae, the presence in Megalonema of a normal intervertebral joint between these centra has been interpreted as a reversal or secondary loss of the synapomorphic sutural joint (Stewart, 1986; Lundberg et al., 1991).

Beyond the aforementioned, the relationships of Megalonema are unsettled. Driver (1919) interpreted similarities of the reduced gas bladders, encapsulating Weberian complexes and external morphology among Megalonema, Luciopimelodus and Pinirampus (as Perugia and including $M$. xanthum) as indicative of relationship, placing these taxa together as the Luciopimelodinae. Alternatively, Stewart (1986) described a number of unambiguous synapomorphies supporting his Calophysus group: Calophysus, Pinirampus, Luciopimelodus, Pimelodina and Aguarunichthys. Stewart found that Megalonema exhibits unique features of the gas bladder and Weberian vertebral structure that set it apart from the Calophysus group, although he pointed out other possible synapomorphies in the reduced structure of the pectoral spine, elevated pectoral-fin ray count and loss of the posterior cleithral process. Lundberg et al. (1991) tentatively leaned toward placing Megalonema basal to the Calophysus group. We are pursuing the question of the systematic position of Megalonema with both morphological and molecular data.

\section{Megalonema Eigenmann, 1912}

\section{Megalonema Eigenmann, 1912a: 150. Gender neuter.}

Type species. Megalonema platycephalum Eigenmann, 1912a, by original designation.

Diagnosis. Eigenmann's (1912a) diagnosis of Megalonema is a mixture of derived and plesiomorphic character states, each with a checkered distribution among pimelodids. Accordingly, we offer an alternative diagnosis emphasizing unique or unambiguous synapomorphies. Thus, Megalonema is characterized by the following. A unique structure of the gas bladder and its encapsulating processes of the Weberian complex (Fig. 1) including: reduced, dumbbell-shaped gas bladder with distended lateral lobes connected by a tubular commissure ventrally crossing Weberian compound centrum; paired, ventrally incomplete bony capsules surrounding lateral lobes of gas bladder formed by deeply down-curved $4^{\text {th }}$ transverse processes of Weberian complex; a prominent ventral flange of compound centrum immediately anterior to tubular commissure of gas bladder and sutural joint with $5^{\text {th }}$ centrum. Paired bony canals of passage for posterior cardinal veins and median aortic canal all very short, formed by ventral flange crossing compound centrum. Bony aortic canal, in some specimens, continued anterior to ventral flange by a second thin midventral bridge (Fig. 1). Transformator process of tripus reduced to a thin tapering splint on anteromedial wall of gas bladder lobe. Vertebral centra five and six articulate by a 


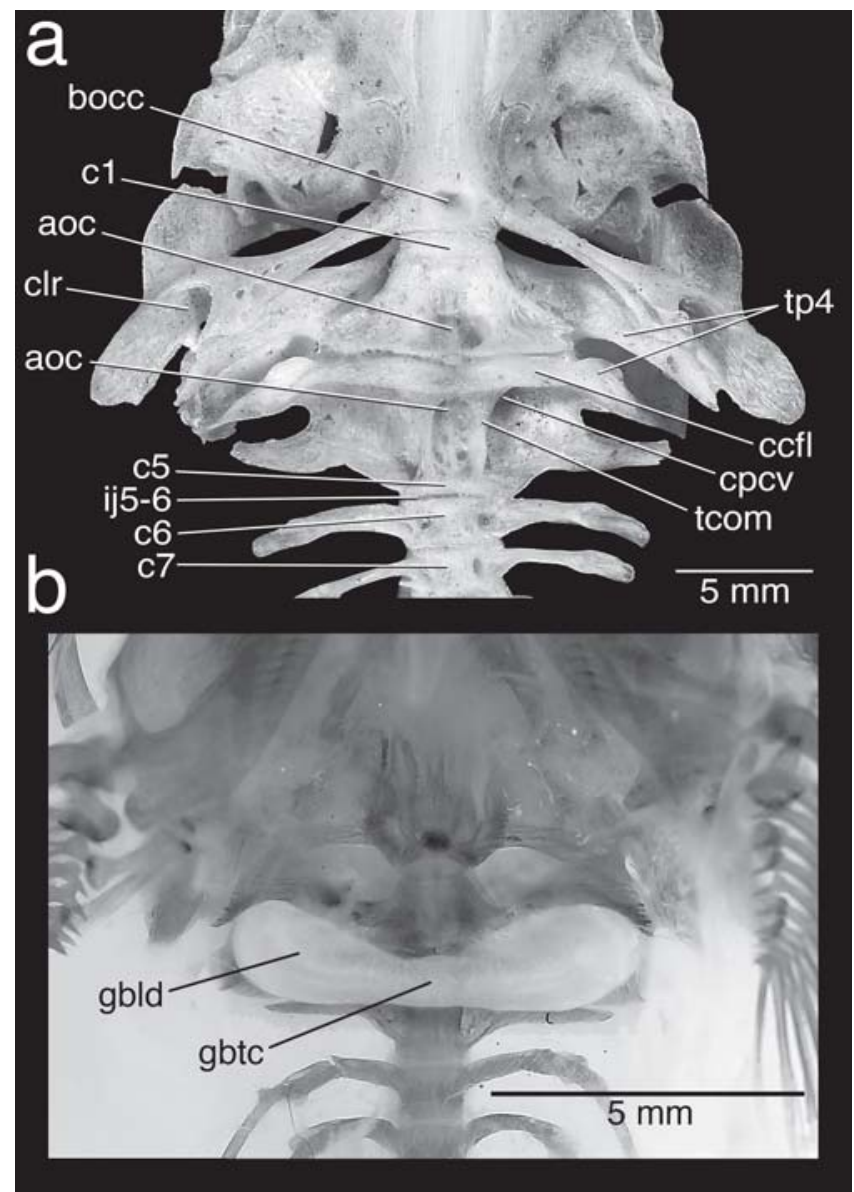

Fig. 1. a, Weberian complex, post-Weberian vertebrae, basioccipital region and upper bones of shoulder girdle of Megalonema cf. platycephalum, ANSP 178515. b, Weberian complex and gas bladder of M. orixanthum, ANSP 187450. aoc $=$ bony aortic canal; bocc $=$ basioccipital; ccfl $=$ ventral flange of compound centrum; tcom = position of gas bladder tubular commissure posterior to ventral flange; $\mathrm{clr}=$ cleithral ring; $\mathrm{cpcv}=$ position of bony canal for passage of posterior cardinal vein; gbld = lateral distention of gas bladder; gbtc = transverse commissure of gas bladder; ij5-6 = typical intervertebral joint between $\mathrm{c} 5$ and c6; tp $4=$ ventrally incomplete bony capsules surrounding lateral lobes of gas bladder formed by deeply down-curved $4^{\text {th }}$ transverse processes of Weberian complex; c1, c5, c6, c7 = vertebrae designated by their ordinal numbers.

typical intervertebral joint without interdigitating sutures, processes or superficial ossification (Fig. 1).

Some other pimelodids possess modifications of the fourth transverse processes for encapsulation of gas bladder: Hypophthalmus (Howes, 1983) and the genera of the Calophysus group (Stewart, 1986; Driver, 1919). Many osteological details of the Weberian complex, however, differ among these groups and Megalonema. Further, the gas bladder morphologies differ strikingly among them: bilobed in Megalonema, small median sac with anterior projections in the Calophysus group, and a pair of small separate sacs in Hypophthalmus.

We also note that Megalonema may have a possibly diagnostic dark caudal spot embedded within the base of upper lobe of the caudal fin, internal to uppermost 4-5 branched fin rays. Some specimens show a matching spot on the lower lobe. We have observed the upper caudal spot in specimens of all species except $M$. argentina (no specimens examined) and $M$. xanthum for which the only available specimens are the faded types collected nearly a century ago. It is possible that $M$. xanthum has the caudal spot in life but it is bleached out as it is in faded specimens of other species. Upper lobe caudal spots in a similar position are also found in Pimelodidae in Hemisorubim, Platysilurus and Platystomatichthys, but in these the pigmentation is chromatophores in the skin, external to the fin rays.

\section{Eretmomegalonema, new subgenus}

Type Species. Megalonema xanthum Eigenmann, 1912, by original designation. We establish this taxon for a subgroup of the genus Megalonema containing M. xanthum, M. amaxanthum new species and $M$. orixanthum new species.

Diagnosis. Eretmomegalonema is uniquely characterized by the paddle-like structure of its pelvic fin and hypertrophied basipterygium (Figs. 2a-b). Both sexes and juveniles exhibit these features. The outer three pelvic-fin rays $\left(1^{\text {st }}-3^{\text {rd }}\right)$ are elongated and a little thickened to form a prominent paddlelike lobe. These rays exceed twice the length of the innermost $\left(6^{\text {th }}\right)$ pelvic ray, and about 1.4 times the length of the $4^{\text {th }}$. The $1^{\text {st }}$ pelvic ray is proximally unbranched and unsegmented for about half its length and its segments are foreshortened (square). The $2^{\text {nd }}$ pelvic ray is similarly unbranched and unsegmented for about half its length, then distally it is asymmetrically branched and segmented as follows. Distal to its first division, the $2^{\text {nd }}$ ray's outer primary ramus does not further divide and its segments are square; the inner primary ramus divides into secondary rami of which the outer ramus remains undivided and with short segments, whereas the inner secondary ramus divides into thin, tertiary rami with more elongated (rectangular) segments. The $3^{\text {rd }}$ ray is unbranched and unsegmented for about $40 \%$ of its length; its primary rami further divide twice and have slightly elongated segments. In contrast to the outer rays, the inner three rays are slender, branched before their midlength, and their segments are elongate rectangles.

The basipterygium is elongated with an overall bony length nearly twice the combined width of both basipterygia. Also, the midline symphysis is complete along the entire length of the anteromedial process, basal plate and posterior process. The posterior process is long and has a triangular shaped tip. On the ventral side, the anteromedial process has a proximal lateral-margin crest. Dorsally, the anterolateral 


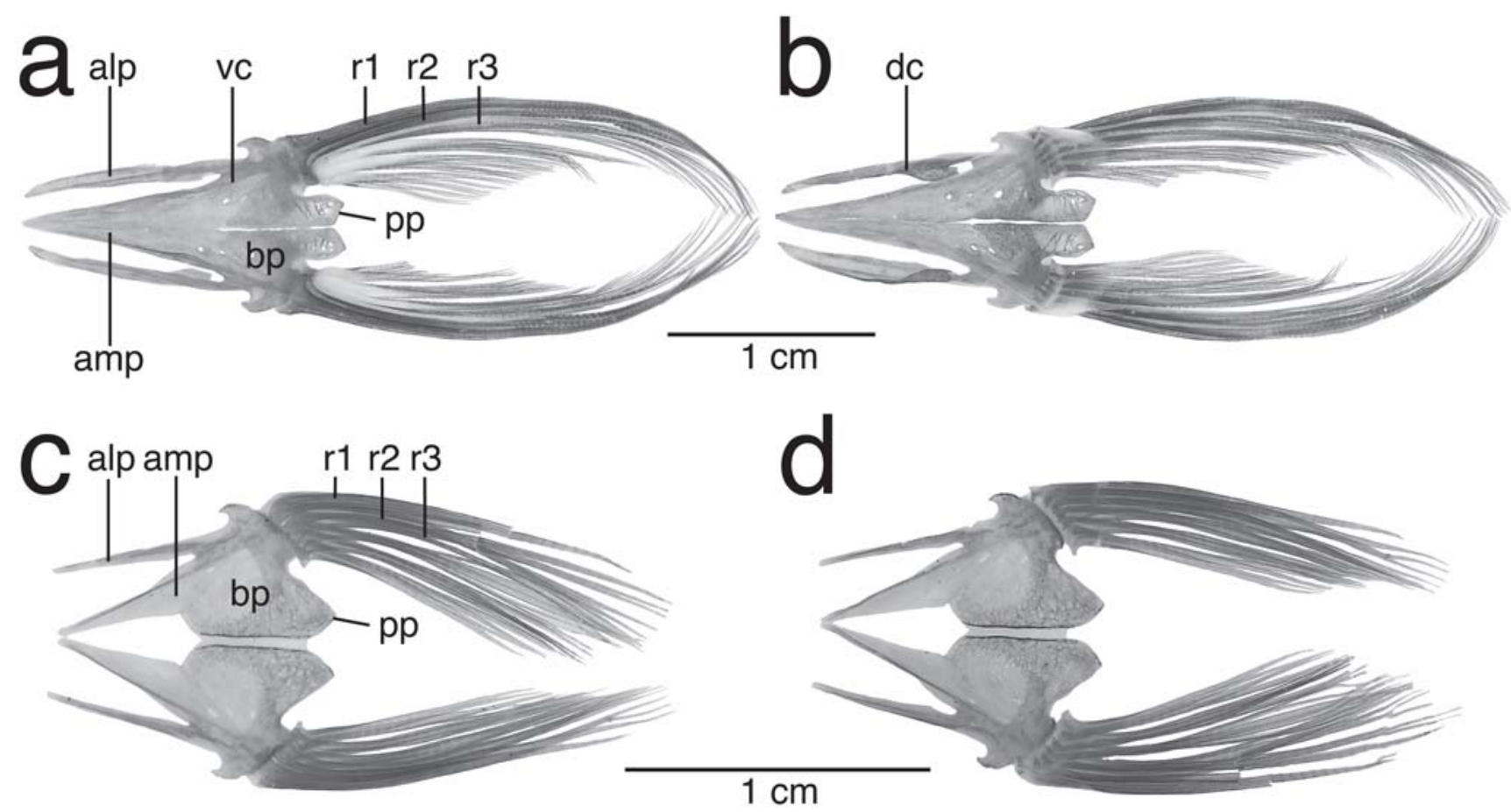

Fig. 2. Pelvic fins and basipterygia in Megalonema orixanthum, ANSP 187450, a, ventral view, b, dorsal view, and $M$. platycephalum, ANSP 189040, , ventral view, d, dorsal view. alp = anterolateral process; amp = anteromedial process; $\mathrm{bp}=$ basal plate; $\mathrm{dc}=$ dorsal crest; $\mathrm{pp}=$ posterior process; $\mathrm{r} 1-3=$ pelvic-fin rays; $\mathrm{vc}=$ ventral crest.

process has on its lateral-margin a prominent high crest that curves medially near its tip. The crests are associated with the arrector, adductor and abductor muscles of the elongated outer pelvic-fin rays.

In marked contrast to Eretmomegalonema, other species of Megalonema (Figs. $2 \mathrm{c}-\mathrm{d}$ ) and other pimelodids lack pelvicfin lobes, although in some the pelvic fins may be generally elongated. Also, no other Megalonema (Figs. $2 \mathrm{c}-\mathrm{d}$ ) or other pimelodids have the high dorsal crest on the anterolateral process (compare Fig. 2b). Also, other species of Megalonema have a wide gap across the midline between the anteromedial processes (Figs. 2 c-d), but a completely bony basipterygial symphysis including the anteromedial processes (compare Figs. 2a-b) is found in some other pimelodids (Parisi et al., 2006; Rocha et al., 2007): Propimelodus, Exallodontus, Pimelodus altissimus, Duopalatinus peruanus, Cheirocerus and the Calophysus group.

Etymology. Subgenus Eretmomegalonema, from Greek eretmon, oar, in reference to the paddle-like pelvic fins, and megalonema, name of the catfish genus to which the new taxon belongs. Gender Neuter.

\section{Key to the species of Subgenus Eretmomegalonema}

1. Supraoccipital posterior process narrow, its basal width less than half its length, its sides gently tapering (Fig. 3b); adipose fin rising steeply and terminating posterior to vertical through tips of adpressed analfin rays; eye small, horizontal diameter contained 5-6 times in head length; pectoral spine with numerous, erect dentations along posterior margin; premaxillary tooth band broad with about 8-10 rows of teeth; 1820 gill rakers on first arch. Magdalena River Basin

...................................... Megalonemaxanthum

1'. Supraoccipital posterior process broad based, its basal width equal to or greater than its length, and its sides abruptly tapering (Figs. 3c,d); adipose fin rising at a shallow angle from back and terminating at or anterior to vertical through tips of adpressed anal-fin rays; eye large, horizontal diameter contained 3-5 times in head length; premaxilla extremely narrow with one row of teeth or none; 25 or more gill rakers on first arch. Cis-Andean distribution. .2

2. Supraoccipital posterior process bell-shaped in outline, its tip blunt and separated by a distinct gap from supraneural (Fig. 3c); pectoral spine lacking dentations, premaxilla with a single row of teeth. Amazon River Basin Megalonema amaxanthum

2'. Supraoccipital posterior process triangular in outline, its tip pointed or bifid and nearly reaching supraneural (Fig. 3d); pectoral spine with numerous, erect dentations along posterior margin; premaxilla with a single row of teeth or teeth absent. Orinoco River Ba$\sin$.............................. Megalonema orixanthum 

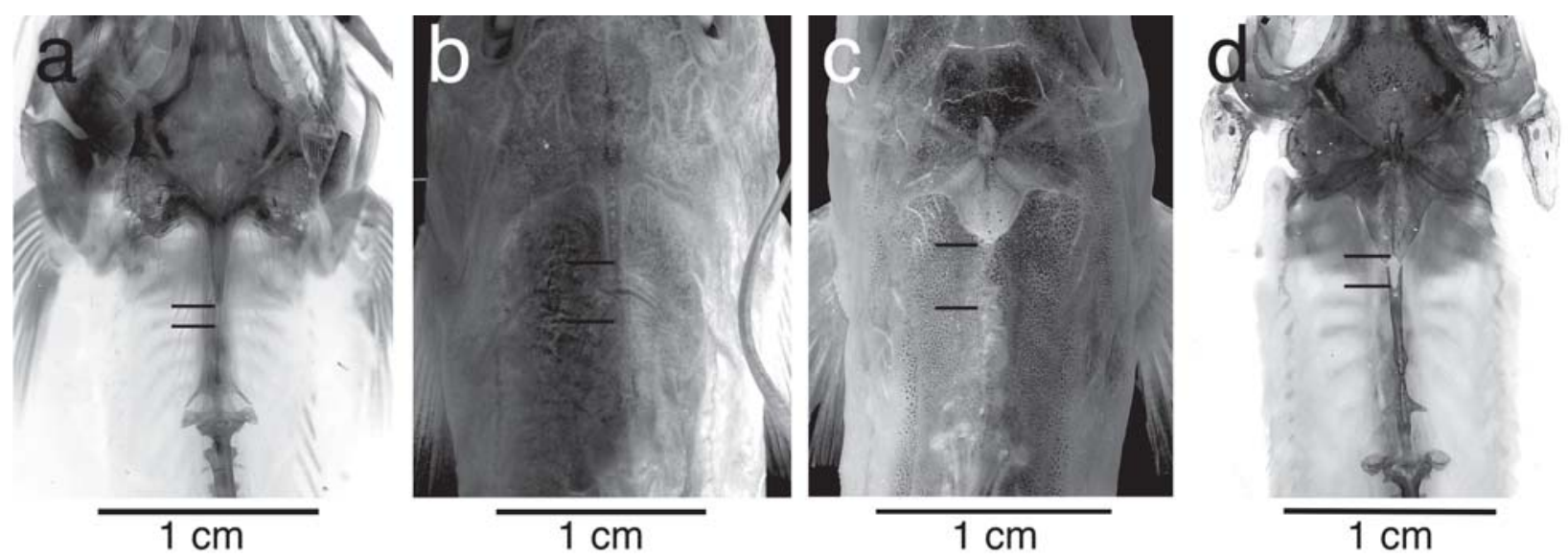

Fig. 3. Details of supraoccipital processes of a, Megalonema cf. platycephalum ANSP 178450, b, M. xanthum CAS 63674, c, M. amaxanthum, holotype, CBF 11896 (ex FMNH 106769), and d, M. orixanthum ANSP 148180, paratype. Paired lines on each image show the gap between the tip of supraoccipital process and supraneural anteromedial point in or just below skin.

\section{Megalonema xanthum Eigenmann, 1912}

Fig. 4

Megalonema xanthum Eigenmann, 1912b: 16 [original description; type locality: Colombia, Cudinamarca Department, Girardot, Magdalena River]. -Stewart, 1986; 670 [anatomy]. -Maldonado-Ocampo et al., 2005: 170, fig. 160, map 162 [description, distribution, specimen list].

Perugia xanthus. -Driver, 1919:453, pl. 2, figs. A, C, D, pl. 3, fig. 5 [anatomy of Weberian complex and gas bladder, in key, relationships]. -Eigenmann, 1922: 35, pl. 3, fig. 3 [holotype photograph].

Diagnosis. A species of the subgenus Eretmomegalonema distinguished from others by the following combination of features. Supraoccipital posterior process (Figs. 4b, 3b) narrow, its basal width less than half its length, its sides gently tapering to a sharp tip separated by a distinct gap from supraneural; adipose-fin (Fig. 4a) large, its margin anteriorly rising steeply and straight or in a broad convex curve to a gently curved apex; adipose fin terminating posterior to vertical through tips of adpressed anal-fin rays; total vertebrae modally 47, range 45-48 (Table 1); eye relatively small, horizontal diameter 154-195 mils of HL; anal-fin base relatively short, 94-117 mils of SL (Fig. 5a); width between posterior nostrils relatively narrow, 138-179 mils of HL (Fig. 5b); pectoral spine with numerous, erect dentations along posterior margin; premaxillary tooth band broad with about $8-10$ rows of teeth; and 18-20 gill rakers on first arch.

Description. Meristic data for 5 to 23 specimens are in Table 1 , and morphometric data for 20 to 23 paratypes are in Table 2. Megalonema xanthum (Fig. 4) is a medium sized pimelodid with a maximum length known to us of $159.3 \mathrm{~mm} \mathrm{SL}$ in the holotype (note that the length of $202 \mathrm{~mm}$ reported by Eigenmann (1912b) is consistent with Total Length). Dorsal profile of head and nape gently convex from snout tip to vertical at insertion of maxillary barbel, then nearly straight to origin of dorsal fin, then body profile scarcely convex along dorsal-fin base, straight to posterior insertion of adipose fin, and a little concave across caudal peduncle. Ventral profile slanting convexly ventrally from snout tip to mental barbels, nearly straight to pectoral-fin origin, straight or convex across abdomen to anal-fin origin, then slanting dorsally to caudal peduncle and slightly concave along caudal peduncle.

Cross-sectional shape roughly trapezoidal from snout to supraoccipital, then deeply and broadly triangular to dorsalfin origin, and increasingly compressed to caudal fin. Maximum body depth at dorsal-fin origin contained 4.5-6.3 times in SL. Maximum body width across cleithra in front of pectoral spine insertion, contained 5.8-6.8 times in SL.

Head of moderate length, contained 4.1-4.8 times in SL and relatively deep, its depth at base of supraoccipital posterior process slightly less than body width. Head covered

Table 1. Frequency distributions for counts of soft pectoralfin rays, gill rakers on first branchial arch, and total vertebrae.

\begin{tabular}{|c|c|c|c|c|c|c|c|c|c|}
\hline & & pec & ral & & & & & & \\
\hline & 11 & 12 & 13 & 14 & & & & & \\
\hline M. xanthum & & 1 & 6 & 5 & & & & & \\
\hline M. amaxanthum & 5 & 9 & 2 & & & & & & \\
\hline M. orixanthum & 1 & 6 & 3 & & & & & & \\
\hline & & & $11 \mathrm{ra}$ & rs o & iirst & ancl & al ar & & \\
\hline & 18 & 19 & 20 & / & 25 & 26 & 27 & 28 & 29 \\
\hline M. xanthum & 1 & 3 & 1 & & & & & & \\
\hline M. amaxanthum & & & & & 1 & & 1 & & 2 \\
\hline M. orixanthum & & & & & & & & 1 & 3 \\
\hline & & & & vert & rae & & & & \\
\hline & 42 & 43 & 44 & 45 & 46 & 47 & 48 & & \\
\hline M. xanthum & & & & 1 & 1 & 18 & 3 & & \\
\hline M. amaxanthum & 21 & 21 & 14 & 5 & & & & & \\
\hline M. orixanthum & & 12 & 21 & 2 & & & & & \\
\hline
\end{tabular}




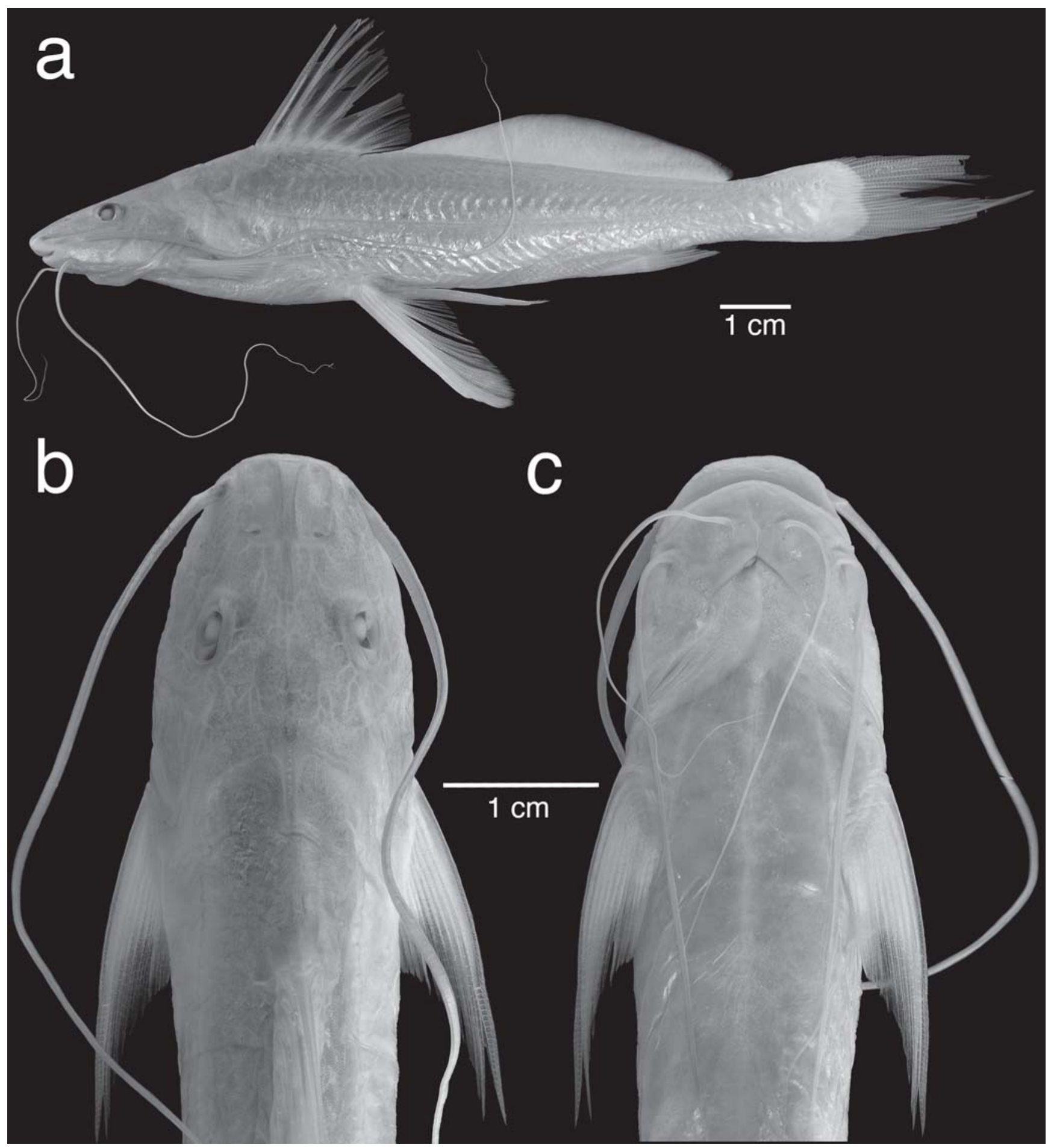

Fig. 4. Megalonema xanthum, CAS 63674, paratype, $118 \mathrm{~mm} \mathrm{SL}$, in a, lateral, $\mathbf{b}$, dorsal and $\mathbf{c}$, ventral view.

by thin skin, skull roofing bones relatively smooth, not ornamented with tubercles or ridges. Snout moderately long, contained 2-2.3 in head length, and with broadly rounded margin in dorsal and ventral views. Snout and upper jaw projecting; with mouth closed less than half of premaxillary dentition exposed. Anterior nostril behind snout margin in a shallow, circular depression, its aperture dorsally directed and encircled with a low fleshy rim; width between anterior nostrils contained 1.2-1.7 times in distance between anterior and posterior nostrils. Long axis of posterior nostril oblique to longitudinal body axis; posterior nostril preceded by thin, semicircular membrane as large as nostril aperture; width between posterior nostrils contained 1.2-1.6 times in distance between anterior and posterior nostrils. Distance between anterior and 
posterior nostrils equal to or a little greater than distance between posterior nostril and eye.

Eye relatively small, about 1.5-2 times longer than deep, placed dorsolaterally and centered on midpoint of bony head length; interorbital space scarcely convex. Interorbital wide, containing horizontal eye diameter 1.2-1.6 times. Anterior cranial fontanelle narrow, parallel-sided, originating behind level of posterior nostrils and terminating between eyes at epiphyseal bar. Posterior cranial fontanelle closed anteriorly, persisting as oval aperture in center of supraoccipital. Supraoccipital posterior process narrow-based (its basal width contained about 3 times in its length), dorsally flat, not angular or keeled, but prominent with sides scarcely tapering to pointed tip, failing by about half of its own length to contact supraneural (anterior nuchal plate obsolete).

Mouth subterminal, opening anteriorly and widely; gape broad, its width across inner surface of ricti twice greater than interorbital width. Lips thin-skinned and smooth. Rictal fold well defined but not fleshy or swollen, subtended above and below by deep folds respectively reaching base of maxillary barbel and about one third distance to mandibular symphysis. Premaxillary tooth band of uniform length along transverse width, with bluntly rounded posterolateral corner. Premaxillary teeth conical, fine, in about 8-10 irregular rows, more numerous in larger specimens. Dentary teeth similarly slender, arranged in about 6-8 rows at symphysis and fewer posterolaterally. No prevomerine, metapterygoid or accessory tooth plates present on the palate.

Origin of maxillary barbel in depression close to base of anterior nostril and above rictus, continuing to below eye; maxillary barbel reaching just beyond posterior end of adipose fin to base of caudal fin. Outer mental barbel reaching near or onto anal fin, not beyond adipose fin. Tip of inner mental barbel reaching near pelvic fin insertion. Branchiostegal membranes anteriorly united to isthmus and overlapping before diverging. Gill rakers long, slender and bladelike, 18-20 on first gill arch (in 5 specimens): 4-5 rakers on upper limb, 1415 on lower limb.

Dorsal-fin lepidotrichia I,7; spinelet absent or vestigial; dorsal-spine base with much reduced articulating processes. Dorsal spine and first branched fin ray distinctly longer than remaining, progressively shorter rays. Dorsal spine slender, its distal half or more segmented and flexible, its shaft smooth and non-serrate. Dorsal-fin origin at vertical through middle of adpressed pectoral fin; its posterior insertion above pelvicfin origin. Adpressed dorsal fin reaches onto adipose fin. Adipose-fin origin located at vertical before or at tip of last dorsal-fin ray. Adipose fin expansive, anteriorly rising straight or convexly to its gently curved apex at vertical about midway between pelvic-fin base and anal-fin origin; terminating posterior to tips of adpressed anal-fin rays; $1.5-2$ times longer than head, relatively high, its height 4.7-6 times in its base.

Caudal fin deeply forked with sharply pointed lobes, the lower lobe shorter, the uppermost two principal rays a little

Table 2. Measurement data for Megalonema xanthum, M. amaxanthum, and M. orixanthum; expressed in thousandths of the standard dimensions given in parentheses. $\mathrm{SL}=$ standard length, $\mathrm{CPL}=$ caudal-peduncle length, $\mathrm{AFB}=$ anal-fin base, $\mathrm{ADL}=$ adipose-fin length, $\mathrm{HL}=$ head length.

\begin{tabular}{|c|c|c|c|c|c|c|c|c|c|c|c|}
\hline \multirow[b]{2}{*}{ Measurement } & \multicolumn{3}{|c|}{ Megalonema xanthum } & \multicolumn{4}{|c|}{ Megalonema amaxanthum } & \multicolumn{4}{|c|}{ Megalonema orixanthum } \\
\hline & Mean & $\mathrm{N}$ & Range & Hol & Mean & $\mathrm{N}$ & Range & Hol & Mean & $\mathrm{N}$ & Range \\
\hline Standard length in $\mathrm{mm}$ & 92.1 & 23 & $64.3-120$ & 98 & 66 & 70 & $40-106$ & 100.3 & 75.4 & 40 & $38.2-115.8$ \\
\hline Predorsal length (SL) & 336 & 23 & $309-354$ & 320 & 343 & 69 & $326-362$ & 337 & 342 & 40 & $326-361$ \\
\hline Preanal length (SL) & 710 & 23 & $688-730$ & 694 & 711 & 70 & $685-741$ & 722 & 709 & 40 & $684-736$ \\
\hline Prepectoral length (SL) & 226 & 23 & $192-424$ & 194 & 221 & 70 & $191-273$ & 210 & 218 & 40 & $196-257$ \\
\hline Prepelvic length (SL) & 435 & 23 & $415-446$ & 436 & 454 & 70 & $429-499$ & 440 & 443 & 40 & $424-471$ \\
\hline Head length (SL) & 229 & 23 & $208-246$ & 214 & 228 & 70 & $205-257$ & 218 & 226 & 40 & $211-246$ \\
\hline Caudal peduncle length (SL) & 204 & 23 & $186-218$ & 219 & 195 & 70 & $178-218$ & 191 & 203 & 40 & $187-219$ \\
\hline Caudal peduncle depth (CPL) & 410 & 23 & $336-474$ & 374 & 423 & 70 & $336-487$ & 385 & 394 & 40 & $326-452$ \\
\hline Dorsal spine length (SL) & 266 & 20 & $243-287$ & 297 & 290 & 59 & $244-371$ & 299 & 288 & 28 & $254-320$ \\
\hline Dorsal fin base (SL) & 140 & 23 & $129-151$ & 153 & 136 & 70 & $108-151$ & 142 & 136 & 40 & $125-147$ \\
\hline Pectoral spine length (SL) & 216 & 21 & $196-230$ & 199 & 217 & 64 & $191-257$ & 217 & 215 & 37 & $192-235$ \\
\hline Pelvic fin length (SL) & 248 & 23 & $233-267$ & 249 & 268 & 70 & $223-327$ & 255 & 266 & 40 & $230-311$ \\
\hline Anal fin height (AFB) & 1490 & 20 & $1311-1637$ & 1252 & 1341 & 66 & $1088-1673$ & 1590 & 1475 & 38 & $1258-1655$ \\
\hline Anal fin base (SL) & 104 & 23 & 94-117 & 106 & 112 & 70 & 93-142 & 100 & 104 & 40 & 93-117 \\
\hline Adipose length (SL) & 393 & 23 & $361-419$ & 366 & 358 & 69 & $311-415$ & 370 & 361 & 40 & $327-387$ \\
\hline Adipose height (ADL) & 185 & 23 & $165-211$ & 185 & 207 & 68 & $165-257$ & 186 & 199 & 40 & $156-246$ \\
\hline Dorsal to adipose distance (SL) & 55 & 21 & $42-78$ & 64 & 63 & 69 & $25-94$ & 44 & 56 & 40 & $38-76$ \\
\hline Body depth (SL) & 191 & 22 & $158-221$ & 191 & 189 & 69 & $161-233$ & 169 & 185 & 40 & $152-226$ \\
\hline Body width (SL) & 161 & 22 & $146-171$ & 141 & 139 & 70 & $118-165$ & 133 & 136 & 39 & $115-155$ \\
\hline Bony interorbital (HL) & 233 & 23 & $204-254$ & 268 & 232 & 70 & $183-285$ & 228 & 231 & 40 & $196-279$ \\
\hline Eye diameter horizontal (HL) & 168 & 23 & $154-195$ & 244 & 263 & 70 & $214-321$ & 260 & 258 & 40 & $209-337$ \\
\hline Eye diameter vertical (HL) & 110 & 23 & $93-136$ & 148 & 158 & 70 & $112-214$ & 169 & 150 & 40 & $105-194$ \\
\hline Snout length (HL) & 476 & 23 & $440-506$ & 450 & 432 & 70 & $373-487$ & 411 & 429 & 40 & $383-483$ \\
\hline Internarial length (HL) & 228 & 23 & $198-260$ & 191 & 188 & 69 & $149-214$ & 183 & 184 & 40 & $145-210$ \\
\hline Internarial anterior width (HL) & 151 & 23 & $125-162$ & 148 & 156 & 70 & $131-177$ & 137 & 149 & 40 & $134-174$ \\
\hline Internarial posterior width (HL) & 160 & 23 & $138-179$ & 177 & 199 & 69 & $162-228$ & 224 & 221 & 40 & $196-246$ \\
\hline Eye to posterior nostril (HL) & 194 & 23 & $172-226$ & 220 & 183 & 69 & $140-227$ & 164 & 183 & 40 & $128-220$ \\
\hline Gape width (HL) & 455 & 23 & $393-497$ & 502 & 457 & 70 & $346-538$ & 425 & 450 & 40 & $372-488$ \\
\hline
\end{tabular}



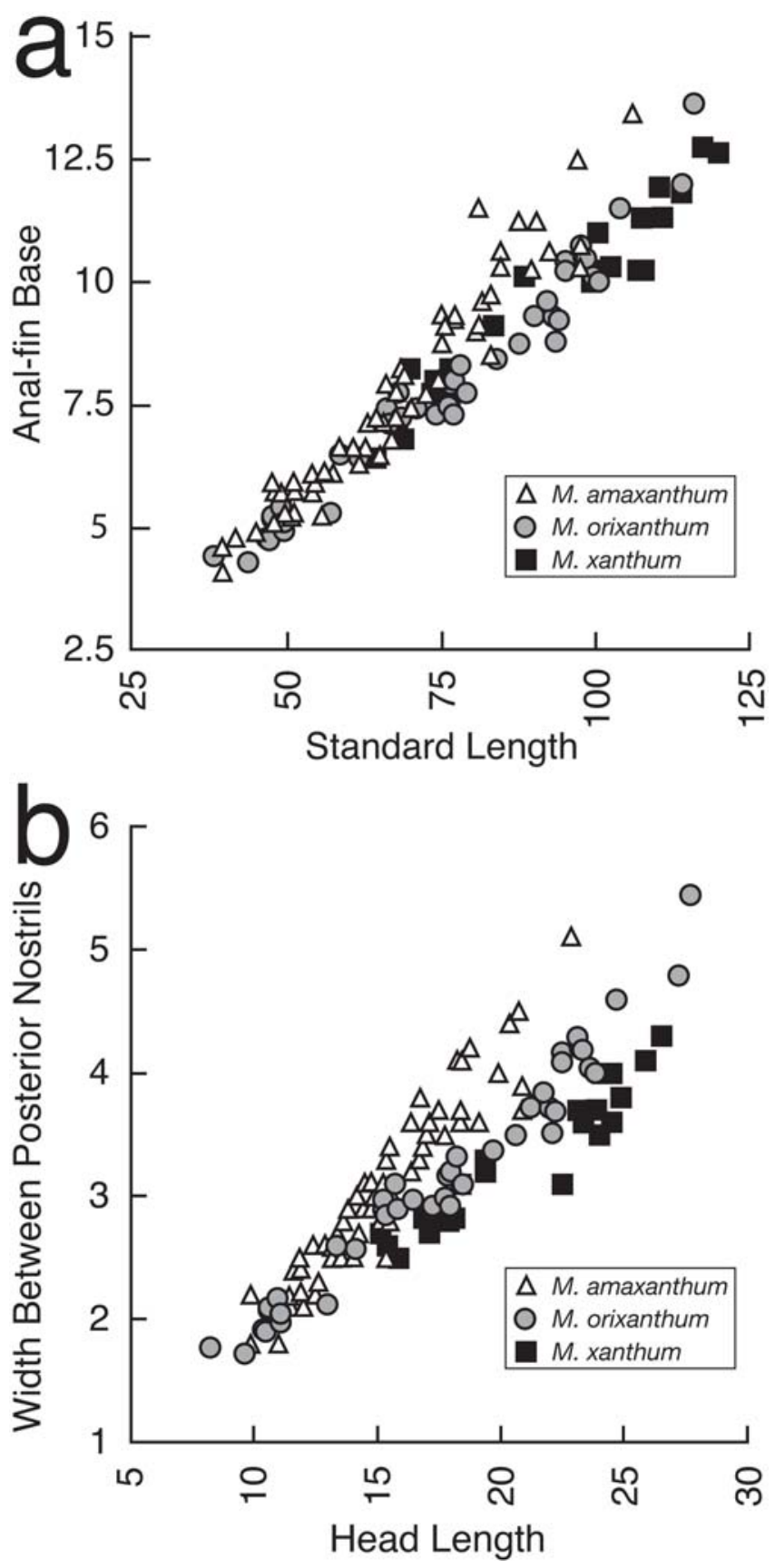

Fig. 5. Scatter plots illustrating: a, anal-fin base length relative to standard length, and $\mathbf{b}$, width between posterior nostrils relative to head length, in Megalonema xanthum (squares, $\mathrm{n}=23$ ), M. amaxanthum (triangles, anal-fin base $\mathrm{n}=71$, width between posterior nostrils $\mathrm{n}=70$ ), and $M$. orixanthum (circles, $\mathrm{n}=41$ ). In t-tests of the residuals from regression, $M$. amaxanthum proved to have a significantly longer anal-fin base length than $M$. orixanthum and $M$. xanthum (p-values $<0.0001$ for pairwise comparisons), and all three species are significantly different from each other in width between posterior nostrils with increasing relative widths from $M$. xanthum, $M$. amaxanthum to $M$. orixanthum ( $\mathrm{p}$-values for pairwise comparisons $<0.0001$ ). prolonged; inner margins of both lobes straight to concave. Principal caudal-fin rays $1+7-8+1$.

Anal-fin origin at vertical through middle of adipose-fin base, posterior insertion before end of adipose fin, distal margin of anal fin slightly concave. Anal-fin rays 13-16, modally 14 , in 19 specimens.

Pectoral fin I, 12-14, modally I, 13, in 11 specimens. Pectoral spine slender, its distal half or more segmented and flexible, its shaft anteriorly smooth, posteriorly with small erect dentations, one per segment where segments are discernable. Pectoral-spine base with much reduced articulating (finlocking) processes. Pectoral spine and outer few branched pectoral rays prolonged but none filamentous. Pectoral-fin margin concave. Pectoral axillary gland pore absent. Posterior cleithral process obsolescent.

Pelvic fin as described for subgenus. Also, pelvic-fin insertion below posterior insertion of dorsal fin. Tip of pelvic fin not reaching anal fin.

Urogenital papilla small, located behind anus near base of inner pelvic-fin rays; no indication of sexual dimorphism.

Lateral line straight with side branches alternating dorsally and ventrally, complete and reaching at least onto caudal-fin base.

Total vertebrae in 23 specimens (Table 1), modally 47, range 45-48 including Weberian complex; in 20 specimens 18-19 precaudal vertebrae, modally 18 , and 27-30 caudal vertebrae, modally 29.

Coloration in alcohol. All available specimens are types collected in 1912 that have faded or darkened in preservative. In addition to the dark retina of the eye, small, dark chromatophores are scattered over the dorsum of head and body. Many specimens show a subcutaneous silvery layer along the lower flanks. No specimens show the upper caudal lobe spot that is present in all other species of the genus, but this may be due to its loss in preservative.

In the original description, Eigenmann (1912b: 17), who collected several specimens, described the color of the species as "Plumbeous, yellow in life." An artist's illustration of $M$. xanthum in Maldonado-Ocampo et al. (2005: 291, fig. 160) shows the ground color as gray and otherwise without pigment pattern.

Distribution. Endemic to the Magdalena River basin, Colombia. Maldonado-Ocampo et al. (2005: 341, map 162) plot two localities for the species in or near the río Magdalena mainstem above the $90 \mathrm{~m}$ elevation contour. All of the types are from localities above $90 \mathrm{~m}$.

Material examined. 48 specimens, all from Colombia, Cundinamarca Department. FMNH 56032, holotype, $159.3 \mathrm{~mm}$ SL, Girardot (see digital images and radiographs online at http:// acsi.acnatsci.org/base/index.html); BMNH 1920.12.20.112-113, paratypes 2, 74-77 mm SL; CAS 63674 [ex IU 12681-82], paratypes 11, 70-118 mm SL (4, 70-118 mm SL), Girardot; FMNH 10285, paratype 1, $107 \mathrm{~mm} \mathrm{SL}$, Apulo; FMNH 10289, paratype 1, $69 \mathrm{~mm}$ 
SL, Apulo; FMNH 77890, 2, 101-126.5 mm SL, Apulo; FMNH 77906, 1, 108 mm SL, Apulo; USNM 76930, paratypes 24, 64-120 mm SL (8, 64-111 mm SL), Apulo; USNM 167852, paratypes 5, 88-114 mm SL, Apulo.

\section{Megalonema amaxanthum, new species}

Fig. 6

Holotype. CBF 11896 (ex FMNH 106769), 98.0 mm SL, Bolivia, Pando State, río Tahuamanu from Boca Nareuda to below Cachuelita, $11^{\circ} 18^{\prime} \mathrm{S}, 68^{\circ} 44^{\prime} \mathrm{W}, 13 \mathrm{Sep} 1996, \mathrm{H}$. Ortega et al.

Paratypes. All records within the Amazon drainage basin. Bolivia, Pando State: ANSP 187452, (ex FMNH 106769), 2, 39-42 mm SL, FMNH 106769, 48, 47-98 mm SL (8, 47-97 mm SL), USNM 393558, (ex FMNH 106769), 2, 81-95 mm SL, all collected with the holotype; AUM 23777, 3, 67-85 mm SL, río Acre at Cobija, 79 Feb, 1982, C. K. Swing et al. Brazil, Acre State: MCP 36198, 1, $85 \mathrm{~mm}$ SL, rio Acre, city of Xapuri, at sand extraction encampment, 10³9’51" S, 68³0’45" W, 22 Jul 2004, R. Reis et al. Amazonas State: ANSP 179213, 1, 81 mm SL, rio Solimões (Amazonas Dr.) below rio Purus, upriver of Manacapuru, collected with $3 \mathrm{~m}$ bottom trawl in channel, 327'02" S, 6045'07" W, 1 Aug 1996, A. Zanata et al. ANSP 187453, 2, 42-77 mm SL, rio Solimões below rio Içá, collected with $3 \mathrm{~m}$ bottom trawl in $1 \mathrm{~m}$ channel, $3^{\circ} 00^{\prime} 26.4^{\prime \prime} \mathrm{S}$, 6752'27.1" W, 23 Nov 1993, J. Lundberg et al., field number JGL 93-122; ANSP 187454, 1, 65 mm SL, rio Solimões below rio Jutaí, collected with $3 \mathrm{~m}$ bottom trawl in $2.5-5.5 \mathrm{~m}$ channel, $2^{\circ} 31^{\prime} 32.7^{\prime \prime} \mathrm{S}$, 66³6’34.8" W, 12 Nov 1993, J. Lundberg et al., field number JGL 93-45; ANSP 187455, 6, 32-60 mm SL (2, 40-59 mm SL), rio Jutaí above rio Solimões, collected with $3 \mathrm{~m}$ bottom trawl in $5-10 \mathrm{~m}$ channel, 252'55.7" S, 6657'37.2" W, 16 Nov 1993, J. Lundberg et al., field number JGL 93-69; ANSP 187456, 10 alcohol and 2 C\&S, 35-64 mm SL (4, 49-64 mm SL), rio Jutaí above rio Solimões, collected with $3 \mathrm{~m}$ bottom trawl in 3.7-12.7 m channel, $2^{\circ} 57^{\prime} 03.8^{\prime \prime}$ S, 6700’26.8" W, 16 Nov1993, J. Friel et al., field number JPF 9376; ANSP 187457, 1, $50 \mathrm{~mm}$ SL, rio Jutaí above rio Solimões, collected with $3 \mathrm{~m}$ bottom trawl in channel, $2^{\circ} 49^{\prime} 33.3^{\prime \prime} \mathrm{S}$, 66 55'06.8" W, 13 Nov 1993, J. Sullivan et al., field number JPS 93-48; CU 84562, 3, 47.1-64.4 mm SL, rio Jutaí above rio Solimões, collected with $3 \mathrm{~m}$ bottom trawl in 8.2-11.1 m channel, $2^{\circ} 53^{\prime} 42.7^{\prime \prime}$ S, 6700’34.5" W, 16 Nov 1993, J. Friel et al., field number JPF 9382; INPA 29490, 1, 48 mm SL, rio Solimões below rio Içá, collected with 3 m bottom trawl in channel, 2०57'58.3" S, 6749'44.4" W, 23 Nov 1993, J. Sullivan et al., field JPS 93-77; INPA 29491, 3, 48-62 $\mathrm{mm}$ SL, rio Negro, collected with $3 \mathrm{~m}$ bottom trawl in $3.6-5.6 \mathrm{~m}$ channel, 2०21'44" S, 49²8'54" W, 10 Dec 1993, M. Garcia et al., field number MG 93-37; MUSM 32629, 1, 63 mm SL, rio Japurá above rio Solimões, collected with $3 \mathrm{~m}$ bottom trawl in 2.9-6.7 m channel, 302'58.3" S, 6446’39.2" W, 29 Oct 1993, O. Oyakawa et al., field number OTO 93-1; MZUSP 99744, 1, $65 \mathrm{~mm} \mathrm{SL}$, rio Solimões, collected with $3 \mathrm{~m}$ bottom trawl in channel, Nov 1993, J. Friel et al., field number JPF 93-143; MZUSP 99745, 1, 51 mm SL, rio Negro below Curidique, collected with $3 \mathrm{~m}$ bottom trawl in 58.5 m channel, $1^{\circ} 58^{\prime} 40.6^{\prime \prime} \mathrm{S}, 61^{\circ} 14^{\prime} 15.6$ " W, 5 Dec 1993, J. Friel et al., field number JPF 93-154; MZUSP 99746, 1, 70 mm SL, rio Negro, collected with $3 \mathrm{~m}$ bottom trawl in 7.7-9.8 $\mathrm{m}$ channel, 141'37.0" S, 61²6’50.1" W, 6 Dec 1993, J. Friel et al., field number JPF 93-158; MZUSP 99747, 4, 42-67 mm SL (3, 51-67 $\mathrm{mm}$ SL), same data as CU 84562. Pará State: ANSP 187458, 1, 48 $\mathrm{mm}$ SL, rio Tocantins above rio Pará, collected with $3 \mathrm{~m}$ bottom trawl in 6-15 m channel, 2²1'44" S, 49²8' 54 " W, 19 Nov 1994, A.
Zanata et al., field number AMZ 94-140; ANSP 187459, 4, 40-45 $\mathrm{mm}$ SL $(2,40-45 \mathrm{~mm} \mathrm{SL})$, rio Tocantins above rio Pará, collected with $3 \mathrm{~m}$ bottom trawl in 5.5-6.9 m channel, $2^{\circ} 23^{\prime} 40.2^{\prime \prime} \mathrm{S}$, 49²8'06.3" W, 19 Nov 1994, J. Lundberg et al., field number JGL 94-116; ANSP 189096, 4, 29.5-38.8 mm SL, rio Tocantins above rio Pará, collected with $3 \mathrm{~m}$ bottom trawl in 3-5 m channel, 2०24'17.5" S, 49²7'55.5" W, 19 Nov 1994, J. Lundberg et al., field number JGL 94-114; IAvH-P 11020, 14, 30-54 mm SL (2, 50-54 mm SL), same data as ANSP 189096; MBUCV V-35377, 4, 54-60 mm SL, rio Tocantins above rio Pará, collected with $3 \mathrm{~m}$ bottom trawl in 15.5-25.5 m channel, 2²6’ $52^{\prime \prime}$ S, 49²6’38" W, 19 Nov 1994, A. Zanata et al., field number AMZ 94-145. Rondônia State: MCP 36200, 1, $69 \mathrm{~mm}$ SL, rio Mamoré, frente ao bairro Cristo Rei no município de Guajará-Mirim, collected with $3 \mathrm{~m}$ bottom trawl in channel, 1047'03" S, 65²0'58" W, 25 Jul 2004, R. Reis et al. Roraima State: AMNH 246010, 5, 60-68 mm SL, rio Branco above rio Negro, collected with $3 \mathrm{~m}$ bottom trawl in 3.7-7.9 $\mathrm{m}$ channel, $1^{\circ} 15^{\prime} 29.0^{\prime \prime} \mathrm{S}, 61^{\circ} 50^{\prime} 37.1^{\prime \prime} \mathrm{W}, 8$ Dec 1993, J. Baskin et al., field number JNB 93-17; FMNH 117835, 1, $51 \mathrm{~mm}$ SL, rio Branco above rio Negro, collected with $3 \mathrm{~m}$ bottom trawl in 4.3-6.7 m channel, 1¹8’31.4" S, 6151'52.3" W, 8 Dec 1993, J. Lundberg et al., field number JGL 93-170; USNM 393559, 1, 67 mm SL, rio Solimões below rio Içá, collected with $3 \mathrm{~m}$ bottom trawl in 5.5-9.2 m channel, 1¹7'55.4" S, 6151'21.0" W, 23 Nov 1993, J. Lundberg et al., field number JGL 93-174. Guyana, Rupununi: ANSP 180494, 2, 72-83 mm SL, Takutu River (R. Branco-Negro Dr.), 3.77 km SSW of Lethem.1 Nov 2003, M. Sabaj et al. Peru, Loreto Department: ANSP 182732, 10, 44-69 mm SL (7, 54-69 mm SL), río Nanay (Amazonas Dr.), large left bank beach upstream from mouth, N of Iquitos, 15 Aug 2005, M. Sabaj et al.; INHS 36643, 1, $49 \mathrm{~mm}$ SL, río Napo (río Amazonas Dr.) mouth of río Mazan, near town of Mazan, 20 Jul 1995, L. Page et al.; INHS 44116, 1, 74 mm SL, río Napo and Quebrada (río Amazonas Dr.), Mazan, $33.3 \mathrm{~km}$ NE Iquitos at bearing $34^{\circ}, 3^{\circ} 29^{\prime} 32.5^{\prime \prime} \mathrm{S}, 7^{\circ} 05^{\prime} 11.9^{\prime \prime} \mathrm{W}, 2$ Aug 1997, M. Sabaj et al.; MUSM 32833, 3, same data as ANSP 182732. Madre de Dios State: ANSP 180628, 2, 79.8-81 mm SL, MUSM 32834, 1, 77 mm SL, río Tahuamanu (Orton - Madre de Dios Dr.), vicinity of San Lorenzo, 1 Aug 2004, M. Sabaj et al.; ANSP 180633, 1, $106 \mathrm{~mm}$ SL, AUM 47794, 1, 93.4 mm SL, INPA 30248, 1, $90 \mathrm{~mm}$ SL, MUSM 32835, 1, $97.5 \mathrm{~mm} \mathrm{SL}$, all río Acre (Purus Dr.), at town of Inapari on border with Brazil, 2 Aug 2004, M. Sabaj et al.

Non-types. All from the Amazon drainage basin. Brazil, Amazonas State: ANSP 187460, 1, $28 \mathrm{~mm} \mathrm{SL}$, rio Jutai, collected with $3 \mathrm{~m}$ bottom trawl in 9.2-15.2 m channel, $2^{\circ} 52^{\prime} 08.5^{\prime \prime} \mathrm{S}, 66^{\circ} 55^{\prime} 45.2^{\prime \prime} \mathrm{W}$, 16 Nov 1993, Lundberg et al., field number JGL 93-70; ANSP 187461, 5, 31-42 mm SL, rio Jutai, collected with $3 \mathrm{~m}$ bottom trawl in 1.7-7.8 m channel, 249’36.4" S, 6654'57.8" W, 13 Nov 1993, Sullivan et al., field number JPS 93-49; ANSP 187462, 1, $33 \mathrm{~mm}$ $\mathrm{SL}$, rio Jutai, collected with $3 \mathrm{~m}$ bottom trawl, 2०52'48.0" $\mathrm{S}$, 66 $57^{\circ}$ '03.2" W, 13 Nov 1993, Sullivan et al., field number JPS 9345; ANSP 187463, 1, $31 \mathrm{~mm} \mathrm{SL}$, rio Jutai collected with $3 \mathrm{~m}$ bottom trawl in 2-4.3 m channel, 2०49'26.1" S, 6654'40.2" W, 13 Nov 1993, Oyakawa et al., field number OTO 93-33; ANSP 187464, 2 , 32-36 mm SL, rio Jutai, collected with $3 \mathrm{~m}$ bottom trawl in 4.9-6.7 m channel, 4.9-6.7, 252'13.9" S, 6658'18.1" W, 16 Nov 1993, Oyakawa et al., field number OTO 93-66. Pará State: ANSP 187465, 2, 28-33 mm SL, rio Tocantins, collected with $3 \mathrm{~m}$ bottom trawl in 4.6-5.7 m channel, 2²4’05.4" S, 49²7’58.9"W, 19 Nov 1994, Lundberg et al., field number JGL 94-115. Roraima State: ANSP 187466, 4, 31-45 mm SL, rio Branco, collected with $3 \mathrm{~m}$ bottom trawl in 3.9 m channel, $1^{\circ} 20^{\prime} 33.6^{\prime \prime} \mathrm{S}, 61^{\circ} 52^{\prime} 21.3^{\prime \prime} \mathrm{W}, 8$ Dec 1993, Lundberg et al., field number JGL 93-176. 


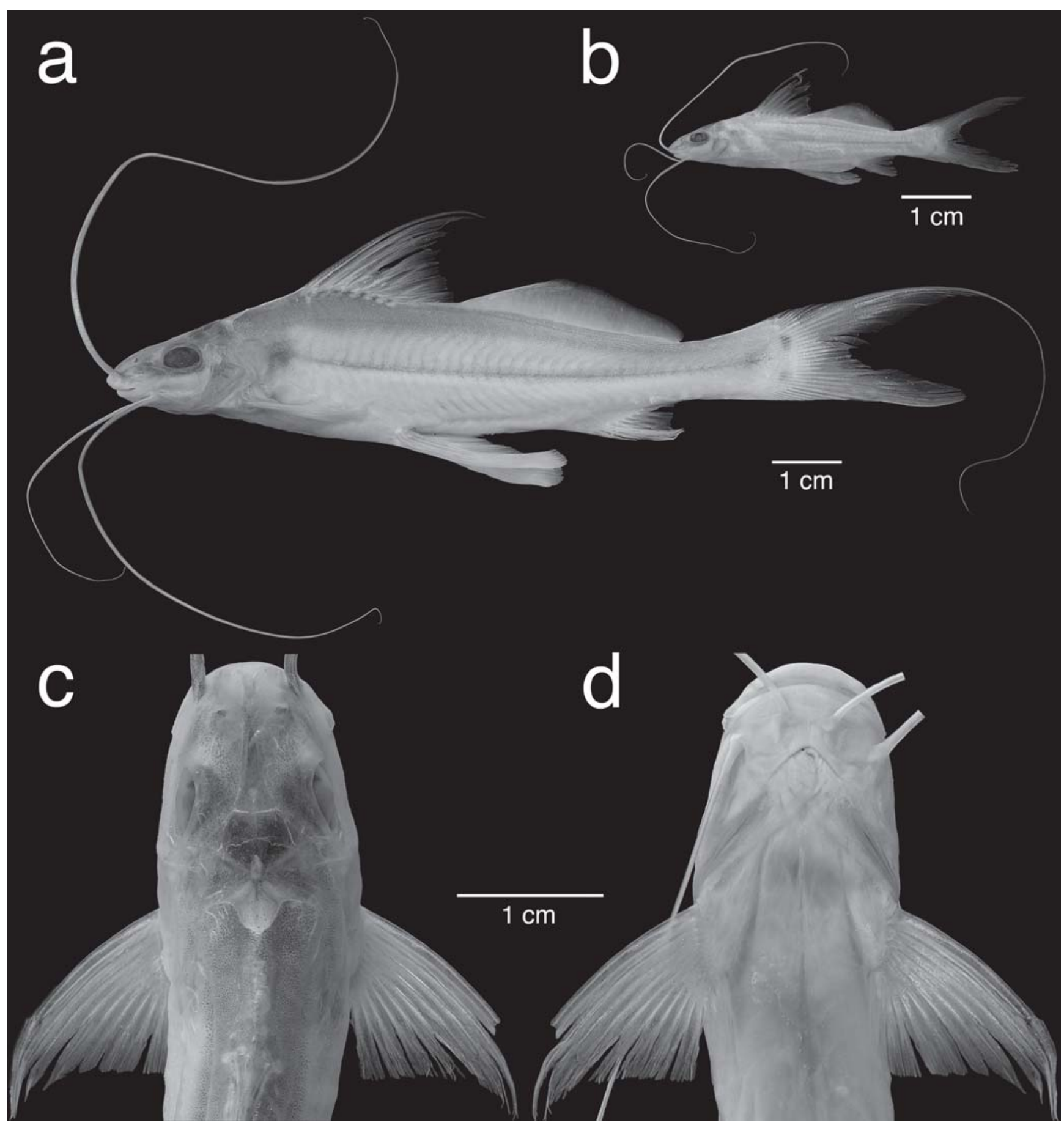

Fig. 6. Megalonema amaxanthum, a, lateral view of holotype, CBF 11896, 98 mm SL, b, lateral view of juvenile paratype, ANSP 187452, $39 \mathrm{~mm}$ SL, c, dorsal and d, ventral view of holotype; distal ends of barbels clipped from images $\mathrm{c}$ and d.

Diagnosis. A species of the subgenus Eretmomegalonema distinguished from others by the following combination of features. Supraoccipital posterior process (Fig. 3c) bell-shaped in outline, broad, its basal width equal to or greater than its length, and its sides convexly tapering to a blunt tip separated by a distinct gap from supraneural; adipose-fin (Figs. 6a,b) margin anteriorly rising at a shallow angle from back and usually in a weakly concave curve to its apex, and adipose-fin terminating at or anterior to vertical through tips of adpressed anal-fin rays; total vertebrae modally 42-43, range 42-45 (Table 1); eye large, horizontal diameter 214-321 mils of HL; anal-fin base relatively long in larger individuals, 93-142 mils of SL (Fig. 5); width between posterior nostrils relatively narrow, 162-228 mils of HL (Fig. 5); pectoral spine lacking dentations; premaxilla extremely narrow with a single row of teeth; and 25-29 gill rakers on first arch. 
Description. Meristic data for 4 to 61 specimens are in Table 1, and morphometric data for 59 to 70 specimens are in Table 2. Megalonema amaxanthum (Fig. 6) is a medium-sized pimelodid with a maximum length known to us of $106 \mathrm{~mm} \mathrm{SL}$. Dorsal profile of head and nape convex from snout tip to vertical at posterior nostril, then nearly straight to origin of dorsal fin, scarcely convex along dorsal-fin base, then less convex to posterior insertion of adipose fin, and gently concave across caudal peduncle. Ventral profile slanting convexly ventrally from snout tip to end of gill region, slightly convex to straight to pelvic-fin origin, abruptly stepped dorsad posterior to pelvic girdle, then straight or convex onto analfin base, slanting dorsally to caudal peduncle and slightly concave along caudal peduncle.

Cross-sectional shape roughly trapezoidal from snout to supraoccipital, then deeply and broadly triangular to dorsalfin origin, and increasingly compressed to caudal fin. Maximum body depth at dorsal-fin origin contained 4.3-6.2 times in SL. Maximum body width across cleithra in front of pectoral spine insertion, contained 6.1-8.5 times in SL.

Head of moderate length, contained 3.9-4.9 times in SL and relatively deep, its depth at base of supraoccipital posterior process equal to body width. Head covered by thin skin, revealing smooth, unornamented skull roofing bones. Snout moderate, contained 2.1-2.7 in head length, and with broadly rounded margin in dorsal and ventral views. Snout and upper jaw projecting; with mouth closed less than half of premaxillary dentition exposed. Anterior nostril behind snout margin in a shallow, circular depression, its aperture dorsally directed and encircled with a low fleshy rim; width between anterior nostrils contained 1.0-1.4 times in distance between anterior and posterior nostrils. Posterior nostril aperture ovoid to subtriangular, preceded by thin, semicircular membrane as large as its aperture; width between posterior nostrils contained 0.8-1.2 times in distance between anterior and posterior nostrils. Distance between anterior and posterior nostrils equal to or a little greater than distance between posterior nostril and eye.

Eye large and somewhat bulging, about 1.5-2 times longer than deep, placed more laterally than dorsally, centered on middle of bony head length; interorbital space convex. Interorbital narrow, containing horizontal eye diameter 0.71.2 times. Anterior cranial fontanelle narrow, parallel-sided, originating behind level of posterior nostrils and terminating between eyes at epiphyseal bar. Posterior cranial fontanelle closed anteriorly, persisting as oval aperture in center of supraoccipital. Supraoccipital posterior process broad-based (its basal width greater than in its length), dorsally slightly convex, not angular or keeled, bell-shaped in outline, with a blunt or rounded tip, failing by about half or more of its own length to contact supraneural (anterior nuchal plate obsolete).

Mouth subterminal, opening anteriorly and widely; gape broad, its width across inner surface of ricti twice greater than interorbital width. Lips thin-skinned and smooth. Rictal fold well defined but not fleshy or swollen, subtended above and below by deep folds respectively reaching base of maxillary barbel and about one third distance to mandibular symphysis. Premaxillary dentition reduced to a single narrow row of fine, conical teeth. Dentary teeth similarly slender, arranged in about 3 rows at symphysis and one row posterolaterally.

Origin of maxillary barbel in depression close to base of anterior nostril and above rictus, continuing to below eye; maxillary barbel reaching onto but not beyond caudal fin. Outer mental barbel reaching at least posterior half or just beyond adipose fin. Tip of inner mental barbel reaching pelvic fin insertion to half of the length of depressed pelvic fin. Branchiostegal membranes anteriorly united to isthmus and overlapping before diverging. Branchiostegal rays 8. Gill rakers long, slender bladelike, 25-29 on first gill arch (in four specimens): 6-7 rakers on upper limb, 1 at cartilaginous angle, 1822 on lower limb.

Dorsal-fin lepidotrichia I,7; spinelet absent or vestigial; dorsal-spine base with much reduced articulating processes. Dorsal-fin spine and first branched fin ray distinctly longer than remaining, progressively shorter rays. Dorsal spine slender, its distal half or more segmented and flexible, its shaft smooth and non-serrate. Dorsal-fin origin at vertical through middle of adpressed pectoral fin; its posterior insertion above pelvic-fin origin. Only the longest anterior fin rays and dorsalfin spine of adpressed dorsal fin reach adipose fin. Adiposefin origin located at vertical posterior to tips of last four dorsalfin rays. Adipose fin large, anteriorly rising with a straight or barely convex margin at a low angle to its base, its apex at vertical near anal-fin origin; terminating at or near tips of adpressed anal-fin rays; $1.4-1.8$ times longer than head, relatively high, its height 3.9-6.1 times in its base.

Caudal fin deeply forked; pointed upper lobe with filamentous unbranched principal ray, the lower lobe narrowly rounded and a little shorter, and none of its rays prolonged; inner margins of both lobes straight to concave. Principal caudal-fin rays $1+7+8+1$. Anal-fin origin below middle of adipose-fin base, posterior insertion before end of adipose fin, distal margin of anal fin slightly concave. Anal-fin rays 12-16, modally 13 , in 40 specimens.

Pectoral fin I, 11-13, modally I, 12, in 15 specimens. Pectoral spine slender, its distal half or more segmented and flexible, its shaft entirely smooth without dentations. Pectoralspine base with much reduced articulating (fin-locking) processes. Pectoral spine and outer few branched pectoral rays prolonged but none filamentous. Pectoral-fin margin concave. Pectoral axillary gland pore absent. Posterior cleithral process obsolescent. Pelvic fin as described for subgenus. Also, pelvic-fin insertion below posterior insertion of dorsal fin. Tip of pelvic fin close to or reaching anal fin.

Urogenital papilla small located behind anus near base of inner pelvic-fin rays; no indication of sexual dimorphism.

Lateral line straight with side branches alternating dorsally and ventrally, complete, and terminating near the ends of middle caudal-fin rays.

Total vertebrae in 61 specimens (Table 1), modally 42-43, 
range 42-45 including Weberian complex; in 61 specimens 1618 precaudal vertebrae, modally 16 , and in 60 specimens 25 28 caudal vertebrae, modally 27.

Coloration in alcohol. Head and body yellowish to tan in background color. Top and upper sides of head and body lightly to moderately covered with small brownish chromatophores. Top of head with dense concentrations of pigment at and posterior to maxillary barbel insertion, on the midline above mesethmoid between light olfactory organs, and along anterior cranial fontanelle except between eyes. Oval posterior cranial fontanelle dark or covered with hyaline skin. Deep lying, quadrangular dark spot across midline between level of eyes and posterior cranial fontanelle. Supraoccipital posterior process pallid, otherwise nape darker. Dark area of variable extent near or on supraneural, middle and posterior nuchal plates, and at insertion of dorsal fin. A variable series of dark spots at bases of dorsal-fin rays. Tympanic area often darker than surrounding sides behind pectoral girdle. Sclerotic coat of eyes dark or silvery. Upper caudal spot generally present. Rayed fins with hyaline rays and transparent membranes; some specimens with chromatophores along dorsal-, caudal-, anal-, pectoral and pelvic-fin rays and on membranes of dorsal and caudal fins. Adipose fin hyaline, with small, widely dispersed chromatophores.

Distribution. Amazon River basin, Brazil, Guyana (Takutu River), Peru, Bolivia, and probably Colombia and Ecuador.

Etymology. The name amaxanthum refers to the distribution of the species in the Amazon basin and its relationship to the species M. xanthum.

\section{Megalonema orixanthum, new species}

Fig. 7

Holotype. ANSP 187449 (ex ANSP 148143), 100.3 mm SL, Colombia, Meta State, río Metica, ca. $3 \mathrm{~km}$ SE of Hacienda Mozambique, $3^{\circ} 57^{\prime} \mathrm{N}, 73^{\circ} 02^{\prime} \mathrm{W}, 24$ Mar 1975, J. Böhlke, et al.

Paratypes. All records within the Orinoco drainage basin. Colombia, Meta State: ANSP 148143, 23, 90-114 mm SL (8, 90-114 mm SL), FMNH 117836, 2, 95-97 mm SL, IAvH-P 11021, 2, 93-96 mm SL, MBUCV V-35380, 2, 90-97 mm SL, MZUSP 99748, 2, 92-96 mm SL, USNM 393560, 2, 85-95 mm SL, all collected with the holotype; ANSP 131337, 1, $92 \mathrm{~mm}$ SL, río Metica, ca. $1.5 \mathrm{~km}$ E of Rajote (Plancha 267), $3^{\circ} 56^{\prime}$ N, 730' $\mathrm{W}, 19$ Mar 1973, W. Saul and W. Smith-Vaniz; ANSP 148142, 2, 77-116 mm SL, río Metica at El Aviso, 359' N, 7259' W, 30 Mar 1975, W. Saul and L. Fuiman; ANSP 148180, 1 C\&S, $98 \mathrm{~mm}$ SL, río Metica, ca. $3 \mathrm{~km}$ SE Hacienda Mozambique, $3^{\circ} 57^{\prime} \mathrm{N}, 73^{\circ} 02^{\prime} \mathrm{W}, 30$ Mar 1975, J. Böhlke et al.; ANSP 148181, 1, $95 \mathrm{~mm}$ SL, río Metica, ca. $3 \mathrm{~km}$ SE Hacienda Mozambique, $3^{\circ} 57^{\prime} \mathrm{N}, 73^{\circ} 02^{\prime} \mathrm{W}, 30$ Mar 1975, J. Böhlke et al. Venezuela, Amazonas State: ANSP 160744, 1, $77 \mathrm{~mm}$ SL, río Orinoco: shores of Isla de Raton, $5^{\circ} 05^{\prime} \mathrm{N}, 67^{\circ} 48^{\prime} \mathrm{W}, 14$ Nov 1985 , B. Chernoff et al.; ANSP 162484, 3, 29-77 mm SL, río Casiquiare (main channel) ca. $1.5 \mathrm{hr}$. from its confluence with río Orinoco, 16 Mar 1987, H. Lopez and O. Castillo; ANSP 162486, 22, 25-48 mm $\mathrm{SL}(3,43-48 \mathrm{~mm} \mathrm{SL})$, río Casiquiare from mouth of río Pamoni to $4.0 \mathrm{~km}$ below mouth, $2^{\circ} 48^{\prime} 00^{\prime \prime} \mathrm{N}, 65^{\circ} 57^{\prime} 00^{\prime \prime} \mathrm{W}, 17$ Mar 1987, B. Chernoff et al.; ANSP 185144, 6, 37-74 mm SL (3, 38-74 mm SL), río Orinoco (Atlantic Dr.), island W of Puerto Venado, $4.5 \mathrm{~km} \mathrm{~S}$ of Samariapo, $56.5 \mathrm{~km} \mathrm{SW}$ of Puerto Ayacucho, 512’25" N, 6748’32" W, 28 Feb 2005, M. Sabaj et al.; AUM 43048, 13, 47-50 mm SL (2, 47-50 mm SL), same data as ANSP 185144; AUM 43845, 2, 79-94 $\mathrm{mm}$ SL, río Orinoco, beach, $16.1 \mathrm{~km}$ E of La Esmeralda, 25 Mar 2005. Apure State: ANSP 160186, 2, 84-87 mm SL, río Meta, ca 40 min upstream from confluence of río Orinoco, $6^{\circ} 18^{\prime} \mathrm{N}, 67^{\circ} 37^{\prime} \mathrm{W}$, 27 Nov 1985, B. Chernoff et al.; ANSP 165236, 5, 61-78 mm SL, río Apure: between río Portuguesa mouth and S.Fernando de Apure airport, 754'00" N, 67³2’00" W, 4 Nov 1989, S. Schaefer et al.; ANSP 187450, 4 alcohol, 1 C\&S, 59-73 mm SL, río Apure between San Fernando and río Portuguesa, collected with $3 \mathrm{~m}$ bottom trawl, 19 Jul 1984, Lundberg et al. Bolivar State: ANSP 160407, 2, 66-71 $\mathrm{mm}$ SL, río Orinoco - río Caura confluence beaches, canals, lagoons \& islands, vicinity Puerto Las Majadas, 7³8’36" N, 6450'W, 23 Nov 1985, B. Chernoff et al.; ANSP 160857, 1, $57 \mathrm{~mm} \mathrm{SL}$, río Cuchivero at Cuchivero ferry crossing, $7^{\circ} 29^{\prime} \mathrm{N}, 65^{\circ} 53^{\prime} \mathrm{W}, 17 \mathrm{Nov}$ 1985, B. Chernoff et al.; ANSP 187451, 1, 71 mm SL, río Orinoco at Ciudad Bolivar, collected with $3 \mathrm{~m}$ bottom trawl in $10 \mathrm{~m}$ channel, $8^{\circ} 09^{\prime} \mathrm{N}, 63^{\circ} 32^{\prime} \mathrm{W}, 8$ Nov 1979, E. Marsh et al., field number ECM $1-79$.

Diagnosis. A species of the subgenus Eretmomegalonema distinguished from others by the following combination of features. Supraoccipital posterior process (Fig. 3d) broadly triangular in outline, its basal width equal to or greater than its length, and its sides tapering straight to a nearly pointed or bifid tip nearly reaching supraneural; adipose fin (Fig. 7a) smaller, its margin anteriorly rising at a shallow angle from back and usually in a weakly concave curve to its apex, and adipose fin terminating at or anterior to vertical through tips of adpressed anal-fin rays; total vertebrae modally 44, range 43-45 (Table 1); eye large, horizontal diameter 209-337 mils of HL; anal-fin base relatively short, 93-117 mils of SL (Fig. 5); width between posterior nostrils relatively broad, 196-246 mils of HL (Fig. 5); pectoral spine with numerous erect dentations along posterior margin; premaxilla extremely narrow with a single row of teeth or teeth absent; and 28-29 gill rakers on first arch.

Description. Meristic data for 4 to 35 specimens are in Table 1, and morphometric data for 28 to 40 specimens (a few specimens lacking data for damaged parts) are in Table 2. Megalonema orixanthum (Fig. 7) is a medium sized pimelodid with a maximum length known to us of $115.8 \mathrm{~mm}$ SL. Dorsal profile of head and nape convex from snout tip to vertical at posterior nostril, then nearly straight to origin of dorsal fin, scarcely convex along dorsal-fin base, then less convex to posterior insertion of adipose-fin, and gently concave across caudal peduncle. Ventral profile slanting convexly ventrally from snout tip to end of gill region, slightly convex to straight to pelvic-fin origin, stepped dorsad posterior to pelvic girdle, 


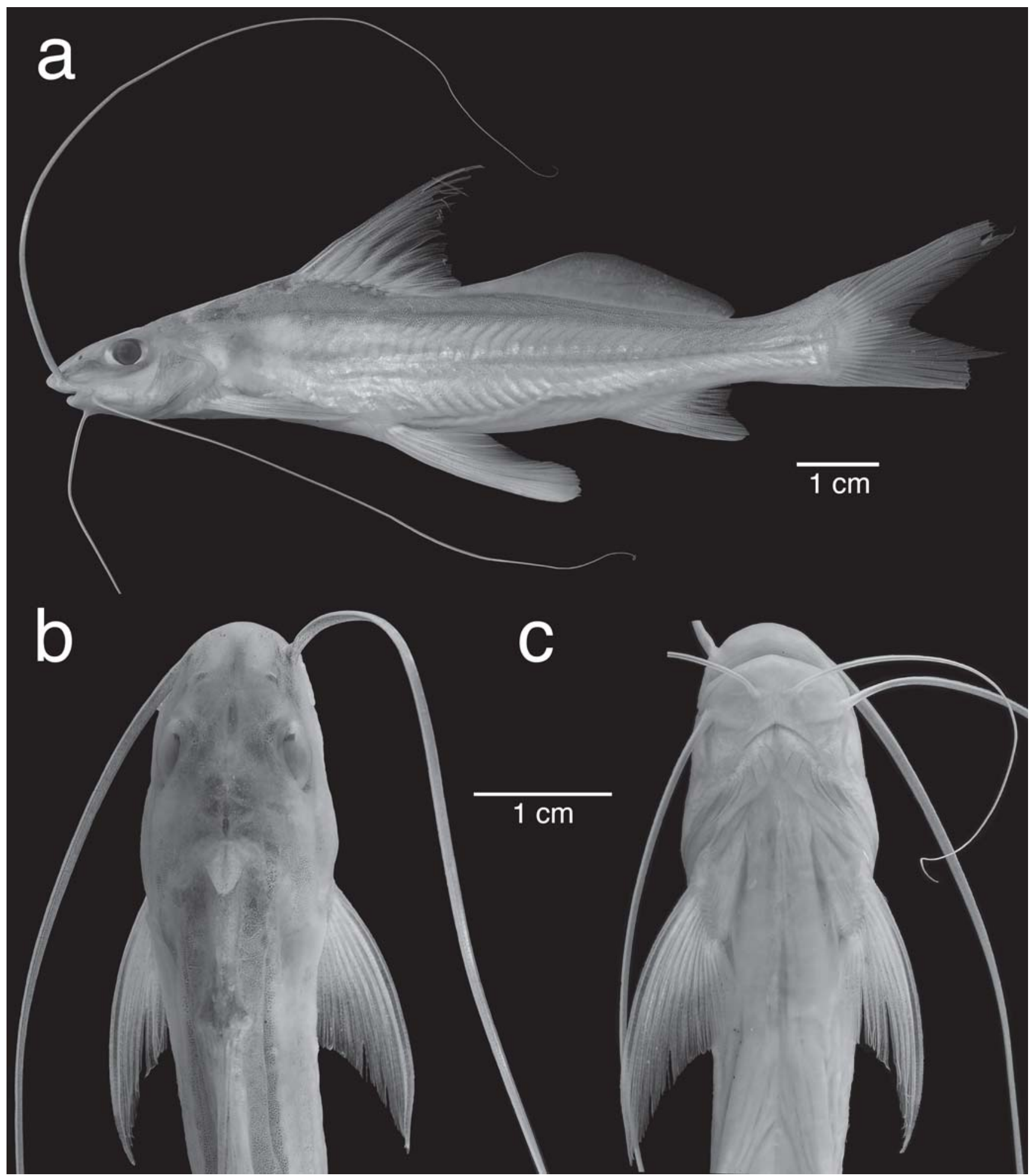

Fig. 7. Megalonema orixanthum, holotype, Colombia, Meta State, río Metica, ca. 3 km SE of Hacienda Mozambique. ANSP 187449, $100 \mathrm{~mm}$ SL, in a, lateral, b, dorsal and c, ventral view; distal ends of barbels clipped from image c.

then convex onto anal-fin base, slanting dorsally to caudal peduncle and concave along caudal peduncle.

Cross-sectional shape roughly trapezoidal from snout to supraoccipital, then deeply and broadly triangular to dorsal- fin origin, and increasingly compressed to caudal fin. Maximum body depth at dorsal-fin origin contained 4.4-6.6 times in SL. Maximum body width across cleithra in front of pectoral spine insertion, contained 6.5-8.7 times in SL. 
Head of moderate length, contained 4.1-4.7 times in SL and relatively deep, its depth at base of supraoccipital posterior process slightly less than body width. Head covered by thin skin, revealing smooth, unornamented skull roofing bones. Snout moderate, contained 2.1-2.6 in head length, and with broadly rounded margin in dorsal and ventral views. Snout and upper jaw projecting; with mouth closed less than half of premaxillary dentition exposed. Anterior nostril behind snout margin in a shallow, circular depression, its aperture dorsally directed and encircled with a low fleshy rim; width between anterior nostrils contained 0.9-1.5 times in distance between anterior and posterior nostrils. Posterior nostril aperture ovoid to subtriangular, preceded by thin, semicircular membrane as large as its aperture; width between posterior nostrils contained 0.7-1.0 times in distance between anterior and posterior nostrils. Distance between anterior and posterior nostrils equal to distance between posterior nostril and eye.

Eye large and somewhat bulging, about 1.5-2 times longer than deep, placed more laterally than dorsally, centered on middle of bony head length; interorbital space convex. Interorbital narrow, containing horizontal eye diameter 0.61.2 times. Anterior cranial fontanelle narrow, parallel-sided, originating behind level of posterior nostrils and terminating between eyes at epiphyseal bar. Posterior cranial fontanelle closed anteriorly, persisting as oval aperture in center of supraoccipital. Supraoccipital posterior process broad-based (its basal width equal to or greater than its length), dorsally slightly convex, not angular or keeled, parabolic in outline, failing by less than half its own length to contact supraneural (anterior nuchal plate obsolete).

Mouth subterminal, opening anteriorly and widely; gape broad, its width across inner surface of ricti twice greater than interorbital width. Lips thin-skinned and smooth. Rictal fold well defined but not fleshy or swollen, subtended above and below by deep folds respectively reaching base of maxillary barbel and about one third distance to mandibular symphysis. Premaxillary toothless or with a single row of a few fine, conical teeth. Dentary teeth slender, arranged in about 3 rows at symphysis and one row posterolaterally.

Origin of maxillary barbel in depression close to base of anterior nostril and above rictus, continuing to below eye; maxillary barbel reaching onto but not beyond caudal fin. Outer mental barbel reaching posterior end of or just beyond adipose fin. Tip of inner mental barbel reaching pelvic-fin insertion to half of the length of depressed pelvic fin. Branchiostegal membranes anteriorly united to isthmus and overlapping before diverging. Branchiostegal rays 8. Gill rakers long, slender bladelike, 28-29 on first gill arch (in four specimens): 6-8 rakers on upper limb, 1 at cartilaginous angle, 2021 on lower limb.

Dorsal-fin lepidotrichia I,7; spinelet absent or vestigial; dorsal-spine base with much reduced articulating processes. Dorsal-fin spine and first branched fin ray distinctly longer than remaining, progressively shorter rays. Dorsal spine slender, its distal half or more segmented and flexible, its shaft smooth and non-serrate. Dorsal-fin origin at vertical through middle of adpressed pectoral fin; its posterior insertion above pelvic-fin origin. Only the longest anterior fin rays and dorsalfin spine of adpressed dorsal fin reach adipose fin. Adiposefin origin located at vertical posterior to tips of last four dorsalfin rays. Adipose fin large, anteriorly rising with a straight or barely convex margin at a low angle to its base, its apex at vertical near anal-fin origin; terminating at or near tips of adpressed anal-fin rays; 1.4-1.7 times longer than head, relatively high, its height 4.1-6.4 times in its base.

Caudal fin deeply forked; pointed upper lobe with filamentous unbranched principal ray, the lower lobe narrowly rounded and a little shorter, and none of its rays prolonged; inner margins of both lobes straight to concave. Principal caudal-fin rays $1+7+8+1$. Anal-fin origin below middle of adipose-fin base, posterior insertion before end of adipose fin, distal margin of anal fin slightly concave. Anal-fin rays 12-15, modally 13, in 27 specimens.

Pectoral fin I,11-13, modally I, 12, in 9 specimens. Pectoral spine slender, its distal half or more segmented and flexible, its shaft smooth anteriorly and with numerous erect dentations along posterior margin. Pectoral-spine base with much reduced articulating (fin-locking) processes. Pectoral spine and outer few branched pectoral rays prolonged but none filamentous. Pectoral-fin margin concave. Pectoral axillary gland pore absent. Posterior cleithral process obsolescent. Pelvic fin as described for subgenus. Also, pelvic-fin insertion below posterior insertion of dorsal fin. Tip of pelvic fin close to or reaching anal fin.

Urogenital papilla small located behind anus near base of inner pelvic-fin rays; no indication of sexual dimorphism.

Lateral line straight with side branches alternating dorsally and ventrally, complete, and terminating near the ends of middle caudal-fin rays.

Total vertebrae in 35 specimens (Table 1), modally 44, range 43-45 including Weberian complex; in 36 specimens 16-18 precaudal vertebrae, modally 17 , and 26-29 caudal vertebrae, modally 27.

Coloration in alcohol. Head and body yellowish to tan in background color; skin translucent often revealing broad subcutaneous silvery band along sides and lower flanks. Top and upper sides of head and body lightly to moderately covered with small brownish chromatophores. Top of head with dense concentrations of pigment at and posterior to maxillary barbel insertion, on the midline above mesethmoid and between light olfactory organs, along anterior cranial fontanelle except between eyes and over oval posterior cranial fontanelle in supraoccipital. Deep lying, quadrangular dark spot across midline between level of eyes and posterior cranial fontanelle. Supraoccipital posterior process pallid, otherwise nape darker. Dark area of variable extent near or on supraneural, middle and posterior nuchal plates, and at insertion of dorsal fin. A variable series of dark spots at bases of dorsal-fin rays. Tympanic area often darker than surrounding sides behind 
pectoral girdle. Sclerotic coat of eyes dark or silvery. Upper caudal spot generally present. Rayed fins with hyaline rays and transparent membranes; some specimens with chromatophores along dorsal-, caudal-, anal-, pectoral and pelvic-fin rays and on membranes of dorsal and caudal fins. Adipose fin hyaline, with small, widely dispersed chromatophores.

Distribution. Orinoco River basin, Colombia and Venezuela.

Etymology. The name orixanthum refers to the distribution of the species in the Orinoco basin and its relationship to the species M. xanthum.

\section{Discussion}

Two unambiguous synapomorphies described in the species diagnoses indicate a sister-group relationship between M. amaxanthum and M. orixanthum within Eretmomegalonema: broad and short supraoccipital posterior process (Figs. $3 \mathrm{c}, \mathrm{d})$ and greatly reduced premaxilla and upper jaw dentition. As inferred from its similarities to species of Megalonema not belonging to Eretmomegalonema, M. xanthum has the plesiomorphic conditions of these elements, i.e. long, narrow supraoccipital posterior process (Fig. 3b, compare Fig. 3a) and broad, well-toothed premaxilla. Thus, trans-Andean $M$. xanthum is considered to be phylogenetically basal within Eretmomegalonema to the cis-Andean species pair in the Amazon and Orinoco. The sequence of two cladistic events in the tree topology of Eretmomegalonema matches the sequence of origin of drainage divides separating the Magdalena, Amazon and Orinoco basins (Lundberg et al., 1998; Lundberg, 2005). The Magdalena watershed was formed and isolated from the Amazon and Orinoco by about $10 \mathrm{Ma}$ in the Middle to Late Miocene when the Eastern Andes was uplifted. The low divides that now separate the Amazon and Orinoco originated later in the Miocene at about $8 \mathrm{Ma}$. The picture that emerges is one of vicariant control of cladogenesis and divergence of the three species in Eretmomegalonema, and the persistence of their allopatric distributions.

Comparative material. Megalonema platycephalum Eigenmann, 1912, Guyana, Demerara-Berbice: ANSP 179249, 1 Sk, 145 mm SL, Essequibo River (east bank) at Kurukupari, 04³9'41"N, 05840’31"W. Rupununi: ANSP 179697, 2, 92-133 mm SL, Rupununi River (Essequibo Dr.) at Kwatamang, $4 \mathrm{~km}$ SE of Annai, $03^{\circ} 55^{\prime} 03^{\prime \prime N}, 059^{\circ} 06^{\prime} 01^{\prime \prime W}$. Megalonema cf. platycephalum. Peru, Loreto Department: ANSP 178450, 2 alcohol, 1 C\&S, 105-110 mm SL, río Nanay (tributary río Amazonas) at Pampa Chica, village $4.54 \mathrm{~km} \mathrm{~W}$ of Iquitos (large beach along $\mathrm{N}$ bank), 345'09"S, $73^{\circ} 17^{\prime} 00^{\prime \prime W}$; ANSP 178515, 1 Sk, río Napo, near town of Mazan, $3^{\circ} 29^{\prime} 10^{\prime \prime}$ S, 7306'24"W. Madre de Dios State: ANSP 187323, 1 Sk, 240 mm SL, río Tahuamanu (Orton-Madre de Dios Dr.), vicinity of San Lorenzo. Colombia, Meta State: ANSP 131341, 45-81 $\mathrm{mm}$ SL, río Metica, upstream from entrance to Lake Mozambique, halfway to entrance to Laguna 'Arrotas.' Venezuela, Apure State: ANSP 189040 (ex DU F998), 6 alcohol, 1 C\&S, 53-76 mm SL, río
Apure between San Fernando and río Portuguesa, collected with 3 $\mathrm{m}$ bottom trawl, 19 Jul 1984, Lundberg et al. Megalonema platanum (Günther, 1880), Brazil, Rio Grande do Sul: MZUSP 78465, 1 Sk, $210 \mathrm{~mm}$ SL, rio Uruguai, em frente ao porto de São Borja. Paraguay, Asunción: UMMZ 207635, 2, 180-205 mm SL, Pettirossi fish market (=Mercado Cuatro), Asunción (from nearby río Paraguay).

\section{Acknowledgements}

For loans of specimens we thank David Catania (CAS, San Francisco), Osvaldo Oyakawa (MZUSP, São Paulo), Francisco Provenzano (MBUCV, Caracas), Mary Anne Rogers (FMNH, Chicago), Roberto Reis (MCP, Porto Alegre), Mike Retzer (INHS, Champaign), David Werneke and Jonathan Armbruster (AUM, Auburn), and Jeff Williams and Richard Vari (National Museum of Natural History). We are most grateful to Kyle Luckenbill (ANSP) for his expert preparation of the illustrations, and to Mark Sabaj Pérez (ANSP) for his assistance with spotting and management of specimens, and many helpful comments on this study. Two anonymous reviewers provided valuable corrections and comments on the manuscript, and we are indebted to the one who voluntarily translated our abstract into Portuguese. Support for travel and publication was provided by the All Catfish Species Inventory (ACSI, US National Science Foundation DEB0315963) and a research award to JGL (US National Science Foundation, DEB-0089612).

\section{Literature Cited}

Driver, C. S. 1919. On the Luciopimelodinae, a new subfamily of the South American Siluridae. Proceedings of the American Philosophical Society, 58:448-456.

Eigenmann, C. H. 1912a. The freshwater fishes of British Guiana, including a study of the ecological grouping of species, and the relation of the fauna of the plateau to that of the lowlands. Memoirs of the Carnegie Museum, 5:i-xxii + 1-578, pls. 1-103.

Eigenmann, C. H. 1912b. Some results from an ichthyological reconnaissance of Colombia, South America. Part I. Indiana University Studies, 16[sic. 8]:1-27.

Eigenmann, C. H. 1922. The fishes of western South America, Part I.- The fresh-water fishes of northwestern South America, including Colombia, Panama, and the Pacific slopes of Ecuador and Peru, together with an appendix upon the fishes of the Rio Meta in Colombia. Memoirs of the Carnegie Museum, 9:1-346, pls. 1-38.

Hardman, M., and J. G. Lundberg. 2006. Molecular phylogeny and a chronology of diversification for "phractocephaline" catfishes (Siluriformes: Pimelodidae) based on mitochondrial DNA and nuclear recombination activating gene 2 sequences. Molecular Phylogenetics and Evolution, 40:410-418.

Howes, G. J. 1983. Problems in catfish anatomy and phylogeny exemplified by the Neotropical Hypophthalmidae (Teleostei: Siluroidei). Bulletin of the British Museum of Natural History (Zoology), 45(1):1-39.

Lundberg, J. G. 2005. Brachyplatystoma promagdalena, new species, a fossil goliath catfish (Siluriformes: Pimelodidae) from the Miocene of Colombia, South America. Neotropical Ichthyology, 3(4):597-605. 
Lundberg, J. G. \& A. Akama. 2005. Brachyplatystoma capapretum: a new species of goliath catfish from the Amazon basin, with a reclassification of allied catfishes (Siluriformes: Pimelodidae). Copeia, 2005:492-516.

Lundberg, J. G. \& M. W. Littmann. 2003. Pimelodidae. Pp. 432446. In: Reis, R. E., S. O. Kullander \& C. J. Ferraris, Jr. (Eds.). Check list of the Freshwater Fishes of South and Central America. Porto Alegre, Edipucrs, 729p.

Lundberg, J. G., F. Mago-Leccia \& P. Nass. 1991. Exallodontus aguanai, a new genus and species of Pimelodidae (Pisces: Siluriformes) from deep river channels of South America, and delimitation of the subfamily Pimelodinae. Proceedings of the Biological Society of Washington, 104:840-869.

Lundberg, J. G., L. G. Marshall, J. Guerrero, B. Horton, M. C. Malabarba \& F. Wesselingh. 1998. The Stage for Neotropical Fish Diversification: A History of Tropical South American Rivers. Pp. 13-48. In: Malabarba, L. R., R. E. Reis, R. P.Vari, Z. M. S. Lucena \& C. A. S. Lucena (Eds.). Phylogeny and Classification of Neotropical Fishes. Porto Alegre, Edipucrs, 603p.

Lundberg, J. G. \& B. M. Parisi. 2002. Propimelodus, new genus, and a description of Pimelodus eigenmanni van der Stigchel, 1946, a long recognized yet poorly-known South American catfish (Pimelodidae: Siluriformes). Proceedings of the Academy of Natural Sciences, Philadelphia, 152:75-88.

Maldonado-Ocampo, J. A., A. Ortega-Lara, J. S. Usma Oveido, G. Galvis Vergara, F. A. Villa-Navarro, L. Vásquez Gamboa, S. Prada-Pedreros \& C. A. Ardila-Rodríguez. 2005. Peces de los Andes de Colombia: Guía de Campo. Bogotá, Instituto de Investigación de Recursos Biológicos Alexander von Humboldt, $346 \mathrm{p}$.

Parisi, B. M., J. G. Lundberg \& C. DoNascimiento. 2006. Propimelodus caesius a new species of long-finned pimelodid catfish (Teleostei: Siluriformes) from the Amazon Basin, South America. Proceedings of the Academy of Natural Sciences of Philadelphia, 155:67-78.

Rocha, M. S., R. R. de Oliveira \& L. H. Rapp Py-Daniel. 2007. A new species of Propimelodus Lundberg \& Parisi, 2002 (Siluriformes: Pimelodidae) from rio Araguaia, Mato Grosso, Brazil. Neotropical Ichthyology, 5(3):279-284.

Stewart, D. J. 1986. Revision of Pimelodina and description of a new genus and species from the Peruvian Amazon (Pisces: Pimelodidae). Copeia, 1986:653-672.

Accepted July, 2008 Published September 30, 2008 